\title{
Happy Times: an Exploration of How Australian Young Adults Define Happiness
}

\author{
Nathan McMillan ${ }^{1}$ (D) Jacqueline Laughland-Booÿ ${ }^{2}$ D . Steven Roberts ${ }^{1}$ (D) \\ Jonathan Smith ${ }^{2}$ (])
}

Received: 19 June 2021 / Revised: 25 October 2021 / Accepted: 25 October 2021 /

Published online: 12 November 2021

(c) The Author(s) 2021

\begin{abstract}
Happiness is an inescapable notion within everyday life and central to the human experience. With evidence that happiness decreases significantly between adolescence and adulthood, this article aims to inform further exploration of why this is so, by first understanding how young people define happiness. In this article, we present data from 29 in-depth interviews with Australian young adults (aged 26-27) in which we asked what they understand happiness to be. From their responses, we found support for a previously proposed typology of happiness. Notably, distinct temporal paradigms emerged in our sample's definitions of happiness not yet considered within previous typologies. These temporal orientations are not only made up of three-time perspectives, past, present and future; furthermore, nuance was identified in temporal outlooks characterised as adaptable, controllable, predictable and uncertain. With early indications that these temporal orientations play a significant role in shaping happiness, this study argues that temporalities are key to understanding the decline of happiness from adolescence to adulthood.
\end{abstract}

Keywords Happiness · Young adulthood $\cdot$ Transition $\cdot$ Time perspectives $\cdot$ Temporal outlooks

\section{Introduction}

Happiness has become a dominant motif in contemporary Western societies as a desirable goal in life (Bastian et al., 2014). Contemporary research has revealed striking trends that indicate that young people report decreasing happiness over time as they transition from adolescence into adulthood (Blanchflower \& Oswald, 2008,

Nathan McMillan

nathan.mcmillan@monash.edu

1 School of Social Sciences, Monash University, Melbourne, VIC, Australia

2 Australian Catholic University, Brisbane, QLD, Australia 
2019; Laaksonen, 2018). To understand this negative trend of happiness, it is imperative that research considers what happiness means to young people. At its core, happiness is a subjective evaluation of one's life which spans multiple life domains (Rojas \& Veenhoven, 2013). However, the way young people define and evaluate their level of happiness can vary considerably between individuals. This variance is shaped by numerous external and societal factors (Rojas, 2005), as well as the different life domains young people perceive as important to achieving happiness (Delle Fave et al., 2016). Understanding such nuance in how young people define happiness may reveal how some mitigate negative trends of happiness more so than others. To explore these nuances within happiness and contributing factors in the decrease of happiness among young people, we must first consider how they define and evaluate their happiness on an individual level.

The purpose of this study is to investigate relevant categories underpinning contemporary young people's everyday definitions of happiness. This is important as the meaning of happiness is not static, but rather changes over time both on an individual (Mogilner et al., 2011) and a sociocultural level (Agbo \& Ome, 2017). A robust exploration of happiness therefore requires ongoing revaluation of everyday definitions of happiness to better inform broader investigations. Establishing this framework is essential for further research to then consider why happiness declines as individuals approach mid-life and what resources might aid in mitigating this pattern.

This article aims to extend our understanding of young people's happiness by qualitatively investigating subjective definitions among young Australians. We do this by analysing in-depth interviews undertaken with a subset of twenty-nine participants from the 'Our Lives' project: a multifaceted longitudinal project which has so far tracked a group of young Australians from adolescence to young adulthood. The contributions made in this research will form the foundation to further explore factors contributing to the decline of happiness in early adulthood. We first outline our relevant literature concerning how young people experience happiness, followed by a brief description of the methodology of this research. The subsequent findings will then be examined, which found general support for a previous happiness typology and the novel observation noting the prominence of temporal orientations within definitions of happiness. The implications and limitations of these findings will then be discussed further to inform future research.

\section{Understanding Happiness}

In recent history, theories of happiness have been predominantly constructed from traditional philosophical discourse with less emphasis on definitions derived from people's lived experiences (Carlquist et al., 2018). Some have explored happiness directly (Agbo \& Ome, 2017; Blanchflower \& Oswald, 2008; Caunt et al. 2013), while others equate happiness to various subcategories of subjective well-being (Hussain, 2017; Piper, 2015). Affective theorists perceive happiness fundamentally as an emotion, how one feels at the time of evaluation or as a culmination of recent pleasant and unpleasant experiences (Veenhoven, 2010). On the other hand, 
cognitive theorists believe happiness is a cognitive evaluation of one's actual life compared to their ideal life (Rojas \& Veenhoven, 2013). However, there is strong evidence to suggest that both affective and cognitive aspects are often included in a person's definition and evaluation of happiness (Agbo \& Ome, 2017; Delle Fave et al., 2011). We adopt a definition that suggests happiness is a subjective evaluation of an individual's affective and cognitive 'condition' (Veenhoven, 2012).

Empirical investigations have explored several factors that may influence happiness, of which age has consistently demonstrated a clear association (Blanchflower \& Oswald, 2008, 2019). The U-shape of happiness suggests that happiness decreases among young people, which continues until mid-life when the trend typically reverses (Blanchflower \& Oswald, 2008, 2019). Though some argue happiness does not increase following mid-life (Bartram, 2020; Glenn, 2009), most scholars agree there is a significant decrease of happiness between adolescence and midlife (Bartram, 2020; Blanchflower \& Oswald, 2019; Laaksonen, 2018).

\section{Young People and Happiness}

Piper (2015) provided further evidence to support this trend, finding a negative linear progression of happiness significantly declining between the ages of 16 and 30 years old. However, the cause of this effect and how it functions remain an important question for the lived experiences of young people. Schwandt (2016) has speculated this may be the result of young people's overly optimistic expectations of the future, where unmet aspirations cause happiness to decrease over time. This framework alludes to temporal dimensions, suggesting that as the discrepancy between young people's present and ideal selves increases their happiness declines. Future orientation has previously been shown to influence various measures of overall well-being, with the propensity to focus on future possibilities correlating with greater well-being over time (Chua et al., 2015).

On a macro level, the downward trends of happiness may reflect broader societal shifts for young people (Wood et al., 2018). Evidence suggests that the transition from adolescence to adulthood is becoming increasingly prolonged within contemporary societies. Life events typically associated with the achievement of adulthood are now gradually becoming more unpredictable and non-linear (Arnett, 2000; Côté \& Bynner, 2008). This is observed in young people moving out from parental home later or returning to the family home, delayed entry to the labour market and entry to graduate-level jobs, as well as extended periods of financial precariousness (Chesters et al., 2019; Tomaszewski et al. 2016; Woodman \& Wyn, 2015). Though with complex and varied social impacts (Roberts and France 2021), the diversification of life pathways has occurred in response to larger-scale structural processes such as globalisation, technological advancement and economic fluctuation (Côté \& Bynner, 2008; France, 2016).

Within this context, happiness has decreased over time among young people navigating their transition to adulthood (Blanchflower \& Oswald, 2008, 2019). The broader social landscape provides the contextual backdrop to consider young people's happiness and the tension between expectations and the lived experience of 
young adults. Researchers have found that they generally expect to experience some traditional life pathways incorporating some combination of marriage, family formation and property ownership (McDonald et al., 2011; Skrbis et al., 2012). Yet, scholars suggest that by the time individuals reach young adulthood, they tend to express an uncertainty towards the future (Amit, 2011; Côté \& Bynner, 2008). In this way, an individual's life pathway and broader social context are thought to be a considerable contributor to early trends of happiness. As Schwandt (2016) suggests, this may occur due to unmet expectations of young people. If this is correct, it is important to acknowledge that not all young people experience this phenomenon in the same way. Before research can effectively explore the relationship between expectations and happiness, investigations must begin at the individual level to consider the implications of everyday experiences (Liao, 2021).

\section{Everyday Definitions of Happiness}

While quantitative measures of happiness deliver trends of reported happiness, qualitative measures are essential to understand the nuances within people's definition of happiness (Torras, 2008). Previous qualitative investigations have achieved this by exploring happiness as it is understood within the context of everyday life (Agbo \& Ome, 2017; Delle Fave et al. 2011, 2016; Pflug, 2009). Asking 'what does happiness mean to you?', Delle Fave and colleagues (Delle Fave et al. 2011, 2016) found that people use a combination of several life domains and psychological definitions to define happiness. The life domains consisted of family, relations, health, daily life, living standard, work, spirituality/religion, leisure, community/society and education. In addition to these external domains, several subcategories of psychological definitions emerged: namely harmony/balance, satisfaction, positive emotions, positive states, optimism, meaning, no negative feelings, awareness, autonomy, engagement/growth, mastery, purpose, self-actualisation (Delle Fave et al., 2016). These categories make up a proposed typology of everyday definitions of happiness and provide the conceptual framework for this study. Such typologies must be routinely revisited to ensure explorations of happiness remain grounded in what people understand in everyday life.

\section{Temporality of Happiness}

The importance of a continual reassessment of happiness is, in part, due to the fluid characteristics of happiness. Mogilner et al. (2011) demonstrated that people change how they define happiness through the life course, in part due to a shifting of attention from the importance of future orientation to a present orientation with age. This indicates that happiness is fluid over time rather than a static notion. An evolving notion of happiness necessitates a periodic review of how people understand happiness in everyday life to inform ongoing empirical investigations. This intrinsic temporal dimension of happiness may also be key in understanding the trends of happiness among young people as they transition to adulthood. 
A tendency towards highly optimistic expectations of the future demonstrated during adolescence may have a direct correlation to happiness outcomes (Schwandt, 2016). If the discrepancy between a young person's present-self and ideal futureself increases, their happiness would theoretically decline because their definition of happiness is founded temporally in the future. Cook's (2016) work on temporalities has demonstrated that despite a broad pessimism towards the future on a macro level, this is not typically reflected in young people's expectations for their own future on an individual level. Generally, young people express a sense of anticipation and possibility, maintaining optimistic personal expectations while acknowledging potential large-scale social upheavals (Cook, 2016). Research has also demonstrated that temporal orientations correlate with reported happiness (Barnett, 2014; Chua et al., 2015). However, less is known about how these dimensions fit within people's everyday conceptions of happiness. To address this gap, this research will incorporate an analysis of young people's temporal orientations.

As Woodman and Leccardi (2015) argue, notions of temporality are central to youth studies as this period of life is most commonly described as a period of significant transition. Adding further complexity, the impact of these temporalities appears to shift on a societal level over time (Leccardi, 2015; Rosa, 2013). However, understanding temporal concepts and their interactions will assist in bringing clarity to questions within youth research (Woodman \& Leccardi, 2015). The decline of happiness for young people navigating the transition to adulthood is no exception. Although notions of temporality have been labelled with a variety of terminology (Drake et al., 2008), this research posits that temporal orientation encapsulates an individual's overall tendency towards specific temporal characteristics, which include time perspectives categorised as past, present or future. Temporal outlooks then provide a necessary nuance to these three basic categories (Boniwell, 2005). Laughland-Booÿ et al. (2017) identified four temporal outlooks classified as adaptable, controllable, predictable and uncertain. Adaptable outlooks describe a general openness to situations and circumstances; controllable outlooks are characterised by a sense of control and self-determination; predictable outlooks rely on a perceived certainty and continuity to one's environment; and uncertain outlooks interpret life through a lens of ambiguity or uncertainty (Laughland-Booÿ et al., 2017). We suggest that these four temporal outlooks exist within each time perspective and provide greater and more observable nuance between people's temporal orientations.

\section{Method}

\section{Participants}

The data for this research come from the 'Social Futures and Life Pathways' project, an ongoing longitudinal study of young people from Queensland, Australia. Also known as 'Our Lives', this project has been following a single-aged cohort of young Australians as they have moved from adolescence into adulthood. Commencing in 2006, seven waves of quantitative data collection have so far been completed, most recently in 2019 ( $n=2042)$. Throughout the study, participants have reported their 
level of happiness. In wave 7 of the Our Lives survey, the wider Our Lives cohort reported a mean happiness level of $7.33(n=2007)$ when asked to respond to the question 'All in all, how happy are you with your life these days?' on a 10-point Likert scale (Skrbis et al. 2020), while our sub-sample of interviewees reported happiness at a mean of $7.14(n=29)$.

As part of the qualitative agenda, a qualitative longitudinal research strategy has been used to follow a subgroup group of the cohort to document their lived experiences. Throughout each interview, data has been collected on participants' aspirations and experiences within key life domains of relationships, career, financial status, education and family formation (Skrbis et al. 2020). To date, these 29 participants (14 women and 15 men) have been interviewed at three points in time spread 5 years apart 2010, 2015 and 2020. The data in this paper relate to the interviews undertaken in 2020, when interviewees were aged 26-27 years old. While most lived in metropolitan areas around Brisbane, Queensland, interviewees were sociodemographically diverse. There is a mixture of those with Australian-born parents $(n=18)$ and those with at least one overseas-born parent $(n=11)$. A small number had recently become parents $(n=4)$, almost half were living with their partner $(n=14)$, while others were living alone $(n=5)$, with housemates $(n=3)$ or with family $(n=7)$. A significant proportion had completed a university qualification $(n=19)$. Of the participants, most were employed at the time of their interview $(n=25)$. Though each of the interviewees was of similar age, there was evident variance in life stages highlighting the prevalence of diversifying pathways as they transition to adulthood (see Appendix for participant summaries). The heterogeneity among our sample's narratives typifies the diversification of life pathways and presents a prime opportunity to explore happiness in this pivotal life stage.

\section{Methodology}

We based our methodological framework on theory pertaining to abductive research strategy, which explores everyday lay concepts produced by participants to explain social phenomena (Blaikie, 2007; Laughland-Booÿ et al., 2017). We adopt the ontological assumption that the world exists independently of perceptions and theories, yet our understanding of this reality is socially constructed (Hoddy, 2019). As Sayer (2010) suggests, social phenomena are concept-dependent, in that they are dependent on what they mean to the members of a society. Therefore, though mechanisms of happiness exist independently of theoretical frameworks, they are intrinsically intertwined with human interpretation due to their subjectivity and dependence on human activity (Archer, 1995). In the context of this paper, we consider how young adults interpret and structure their definition of happiness with the intention to inform theoretical frameworks used to describe its underlying mechanisms.

\section{Procedures}

All interviews were conducted either face-to-face or over the phone. Interviews adopted a semi-structured design and on average were an hour in length. During 
each interview, participants were asked, 'What does happiness mean for you?' The subsequent responses were first thematically coded by the first author. The analysis was then cross-checked and discussed by the other authors until consensus was reached. Our initial categorisation of thematic codes was informed by the typology of happiness presented by Delle Fave and associates (Delle Fave et al. 2016). During the thematic coding process, researchers allowed for openness to incorporate new labels if response did not fit the existing framework.

Subsequent coding occurred in response to the identification of temporal dimensions evident in participants' responses. Within people's definitions of happiness, we identified three-time perspectives; past, present and future. Building on the work of Laughland-Booÿ and colleagues (Laughland-Booÿ et al. 2017) and Brannen and Nilsen (2002), we also identified four temporal outlooks within our data: adaptable, controllable, predictable and uncertain. These outlooks provide greater nuance to understand differences between those who share the same time perspective.

\section{Findings}

To present our findings, we first discuss young people's definitions of happiness in the context of previous typologies of lay conceptions of happiness presented by Dell Fave and colleagues (2016). This will provide insight for future research to better understand the nuances within how people define and report happiness. We then discuss the major findings regarding temporal orientations emerging from the data.

\section{Everyday Understandings of Happiness: Definitions}

Consistent with previous research, there was clear diversity among the definitions of happiness provided by participants (Delle Fave et al., 2016; Hussain, 2017; Rojas, 2005). When asked, 'what does happiness mean for you', participants provided a range of responses supported by anecdotes and evaluations of various domains to contextualise their definition (Agbo \& Ome, 2017; Caunt et al., 2013; Pflug, 2009). Dell Fave and associates (Delle Fave et al. 2016) proposed a comprehensive typology incorporating eleven life domains commonly used to define happiness; psychological definitions, family, relations, health, daily life, standard, work (career), spiritual/religion, leisure, community/society and education. Our study identified each of these categories. In line with previous research (Delle Fave et al. 2011, 2016), psychological definitions were the most prominent component of definitions among our sample of young people, followed by relations, work (career) and then family. However, in contrast to previous studies, physical health was the least mentioned domain, mentioned by only one participant (Delle Fave et al. 2011, 2016). In response to the prominence of psychological definitions, Delle Fave and colleagues (Delle Fave et al. 2016) identified 13 subcategories consisting of harmony/balance, satisfaction, positive emotions, positive states, optimism, meaning, no negative feelings, awareness, autonomy, engagement/growth, mastery, purpose and self-actualisation. Each of these categories was also clearly evident in our data. Harmony/balance was most 
mentioned, followed by self-actualisation, and then engagement/growth, positive states and positive emotions equally. These findings show that previous literature exploring the meaning of happiness remains generally adequate in understanding how young adults define happiness in everyday life (Agbo \& Ome, 2017; Delle Fave et al., 2011; Pflug, 2009).

\section{Time Perspectives}

A striking result that emerged from our data was the prominence of temporal orientations within our sample's definition of happiness. The effects of time perspectives on happiness levels have been considered in past research with varying results (Felsman et al., 2017). However, time perspectives are seldom considered within typologies of everyday definitions of happiness. Our data showed that each response given to the question, 'What is happiness to you?', contained at least one allusion to a time perspective categorised as past, present or future, with some incorporating a combination of these categories.

At the time of their interview, Jacob was working a stable office job and cohabitating with his partner. Displaying a past-orientated perspective, for Jacob, happiness was contextualised by directly relating each example to the past.

It's when things get done or things are not as chaotic as they normally are, some level of success or control in terms of my achievements. So, if I was to say for the last five years, if you had asked me five years ago if I was happy, I'd probably say, "Yeah, not really," because everything was a struggle. I had no control, and it was just going with the flow at the time. Jacob (male)

In broad reflection, he evaluated happiness in the context of a comparison between his perceived present stability and the relative instability of the past. The past is the reference point for his definition of happiness in the present, with control as the focal point of his positive progression over time. This theme was evident throughout the interview. This perspective was also prominent for Olivia as she had recently experienced significant relational turbulence ending in divorce and a fresh start in multiple domains of life, including career, living arrangements and finances. Her experiences provided a perspective that reflected on the then and the now to ground her definition of happiness, explaining:

I feel in control and I feel more equipped with everything that's happened to make more informed decisions, and I feel that everything I've gone through has been such a resilience building exercise. Olivia (female)

Others emphasised the present in their definition of happiness. Laura, a full-time youth worker, described happiness as being satisfied with her current circumstances. As Laura explained, 'I'm happy and grateful for what I have at the moment'. In the evaluation of her potential future happiness Laura said: 
I'm quite content and happy with my life, how it is. The few things that will change, they don't take away from my happiness. I think that would just add to it. Laura (female)

Here, happiness is grounded and defined in how things are in the present. The future can add or subtract happiness, although there is a genuine sense of happiness being present in the now. This sentiment was echoed by others, such as Dylan (male) who described happiness as 'being nicely settled at the moment. Things aren't working exactly how I want them to be working, but they're working, and I'm working. And I am busy, and I really appreciate being busy'. Dylan was living with his longterm partner and established a career path that he was enjoying. The emphasis on the present was notable for Dylan. As he explained, he was settled at the moment. Though things were not exactly as he wanted them to be, he demonstrated a willingness to adapt to life as it unfolded in the present.

There were also those who strongly associated happiness with future possibilities. Jade, for instance, described her happiness as linked to the present, but then also added that happiness was about being excited for the future, which involved:

having opportunities out there, having options, and enjoying the now, but also being excited for the future and moving forward and experiencing new things. Jade (female)

Also, she was already satisfied with her current circumstances, having lived abroad and enjoying a job she had aspired to, her description of happiness incorporated a future perspective.

Others based their perception of happiness solidly on the future, whether it be a distinct goal or a more nebulous ideal. For example, Kyle (male) firmly planted his definition of happiness in a future goal, and whether progress was being made towards it, by saying, 'I think the biggest thing is financial stability and being on the right track with that, both career-wise and asset-wise'. Though he was in a stable relationship and well established in his career in a lucrative sector, happiness for Kyle is in the future. Happiness was externally located in the achievement of future financial stability, which drives his day-to-day focus. Kyle's happiness is mediated by an evaluation of where he is in relation to that goal, seemingly drawn from the level of certainty he has in the accessibility of his goals.

Each example shows how these three-time perspectives are used to frame the way young people define happiness (Boniwell et al., 2010). We suggest happiness is dependent on either one or a combination of two dominant processes; the accessibility of externally located sources of happiness, such as achievements or goals (Headey, 2008); and the internally located source of happiness derived from a comparison of two or more temporal identities, such as present self and future self (Schwandt, 2016). Past perspective requires some experience of significant life events to reflect upon, while future perspectives of happiness tended to rely on some certainty in how life would unfold. Present perspectives either emerged from a lack of future vision or past experiences, or from a general acceptance that both the past and future are out of one's direct control. 


\section{Temporal Outlooks}

Our data also revealed variations in outlooks between young adults who adopt the same time perspectives lending support to Laughland-Booÿ et al. (2017) who identified four temporal outlooks, described as adaptable, controllable, predictable and uncertain.

An adaptable outlook describes a general openness to life's circumstances irrespective of uncontrollable factors. For instance, Liam (male), currently in a longterm cohabitating relationship and stable career path, described happiness as having 'a peaceful mind and not to be worrying about all of the things in the world that are outside of our control...' It is about accepting the positives and negatives in life. This is endorsed also by Chloe, who had recently relocated cities to pursue career advancement, who said:

There's problems and troubles that we all face in everyday life, and you can't ever get rid of them, but I think happiness is when you've reached the point where you know you've got enough to get you through. Chloe (female)

In both cases, there was an acceptance that future events, positive and negative, are unknown and yet inevitable. This acknowledgement, however, was grounded in reflection on the past for both Liam and Chloe. Life had not eventualised specifically as they previously anticipated, and yet, both were content with life outcomes thus far. Happiness was defined as adapting to find contentment irrespective of one's environment.

In contrast, a controllable outlook is demonstrated in the need to control one's environment. After demonstrating his definition of happiness which was firmly orientated towards the future, Kyle (male) continued by saying 'It's probably a bit up in the air, depending on what sort of moves I make over the next two years really...'. For Kyle, happiness is defined as future financial stability and consequent outcomes depend on the 'moves' he consciously makes. This emphasises the need for control and displays a high level of self-determination, with little expressed allowance for unpredictable elements of life.

Predictable outlooks rely on a perceived certainty and continuity to one's environment (Brannen \& Nilsen, 2002). This was evident for Brianna (female), who believed she was on a stable career path and preparing to be married at the time of her interview. After changing career direction, Brianna was content with major domains in her life, and her happiness was found in the consistency of that contentment in the present. She demonstrated a clear sense that happiness exists in the continuity of valued areas of life, a secure relationship, an ongoing stability and enjoyment of everyday life.

I think happiness is... being content in life and enjoying your work and having fun with [partner's name] and having someone to come home to that's always there and very loving. In terms of mood and things like that, I've always been pretty stable and I tend to be very stable in my mood. I don't really have too many big lows. In a way, I don't have huge highs. I feel like I'm generally 
pretty happy most of the time. It's just enjoying what you're doing. Brianna (female)

Predictable outlooks differ from controllable outlooks as the certainty associated with life events is not always in the direct control of the individual. Rather, the consistency of internal and external environments is key in sustaining happiness.

Uncertain outlooks, however, interpret temporal orientations through a lens of ambiguity or uncertainty. For instance, Luke, who has experienced significant personal and mental health challenges, adopted a future time perspective and their outlook was characterised by uncertainty.

So, I don't know, being fulfilled, I guess, would be the answer... I would like just to have a stable - Like after I finish my degree, maybe one day a stable job. I've now got this social group and the social connections that I always wanted in the past. I've now got that. I have achieved that, and that makes me so happy. Eventually some significant other. That would be nice. Luke (male)

For Luke, happiness was defined as the fulfilment of specific goals. He explained that his recently achieved social goals provided happiness at the time of the interview. Despite this happiness, he expressed his doubt in the longevity of these social connections and in turn his current level of happiness. This resonated with his broader experience of anxiety and placed happiness in an almost unattainable location. If it could be attained, there was doubt in its permanence.

\section{Discussion and Conclusion}

The purpose of this research is to understand how young people define happiness. This exploratory study aims to inform the broader question of why happiness decreases among young people as they transition to adulthood. Knowing how happiness is understood within everyday life provides a framework to then reflect on factors influencing this evident negative trend of happiness. Our data reveal several key observations significant in extending our understanding of how young people conceptualise happiness. We found clear support among our young Australian sample for the typology of happiness proposed by Delle Fave and associates (Delle Fave et al. 2011, 2016), with the only significant difference being the limited emphasis our sample of young people placed on physical health. Given that several of our interviewees have experienced significant health challenges, health was unexpectedly included in only one participant's definition of happiness. Considering the role of temporalities, which has become a central theme of our findings, it is possible that beliefs of temporal distance from perceived older age would cause health to be less prominent in the everyday evaluations of happiness among younger people (Mogilner et al., 2011). This would suggest that temporalities, in part, shape which life domains are valued among young people, particularly how they situate themselves in relation to their perceived future. This speculation prompts further consideration to understand how young adults perceive health in relation to their happiness and to explore potential outcomes connected to any lack or emphasis of this association. 
Significantly, our data highlighted the prominence of temporal orientations within definitions of happiness. These temporalities were apparent in all the definitions provided by participants incorporating time perspectives: past, present and future (Drake et al., 2008), and temporal outlooks: adaptable, controllable, predictable and uncertain (Boniwell, 2005). Thus far, notions of temporal orientation have been notably absent from previous research exploring everyday definitions of happiness. However, we believe that these temporal orientations, and the subsequent variations adopted by individuals, are key to understanding the decline of happiness from adolescence to adulthood: both on a societal level and the nuances of this experience at an individual level. As shown by Mogilner et al. (2011), the time perspective associated with happiness changes from predominantly future-orientated to mostly present-oriented through the life course. We suggest that the change in time perspective correlates in some way to the decline in happiness among young people over time. If young people adopt a future orientation within their framing of happiness and these aspirations are not met, or begin to appear less likely with age, this may contribute to a decrease of their happiness (Schwandt, 2016). Additionally, as Cook (2016) observed, there is evident disparity between the optimism young people generally perceive in their personal future and the pessimism often expressed towards the future on a societal level. The decrease in happiness may also be a result of reckoning with this disparity. The change in time perspectives may reflect an adaptation in one's framing of happiness to mitigate further negative impacts. Within our sample, a present focus was sighted most often within their meanings of happiness. This raises further questions as to when, if at all, this adaption takes place and how long it takes for such change to impact happiness levels. Future research would also benefit from focusing on the impact of any disparity between expectations (expected life, as derived from relative certainty) and aspirations (ideal life, as derived from hopes) among young people as they transition to early adulthood. This would help identify whether the tendency towards highly optimistic expectations contributes to the evident decline of happiness through this stage of life.

Adding nuance within the three observed time perspectives, we found evidence that temporal outlooks shape which domains are most important for young people's definition of happiness (Boniwell, 2005; Laughland-Booÿ et al., 2017). Young people with uncertain outlooks were more likely to place greater emphasis on life domains rather than psychological definitions. This was also apparent for those who adopted controllable outlooks. We believe this is, in part, due to both groups basing their sense of happiness in more external factors. For instance, those with a controllable outlook were likely to draw a sense of happiness from the certainty they perceived in domains such as work, education or financial achievements. Predictable outlooks tended to more frequently emphasise psychological definitions than other outlooks. Young people with this outlook were also more likely to adopt a present time perspective highlighting the importance of focusing on the now and being content with how life is at present. Adaptable outlooks were similar in their affinity towards the present. In both predictable and adaptable outlooks, young people's temporal orientations were built on life experiences that resulted in a general acceptance that there is little direct control over the past or future. Theoretically, this would render adaptable outlooks the most beneficial in terms of happiness levels, 
due to the inherent disposition to accept what is largely uncontrollable. Amidst the unpredictability associated with the transition to adulthood (Arnett, 2000; Côté \& Bynner, 2008), a temporal outlook less reliant on certainty is thought to be beneficial. Whereas the happiness of those who adopt controllable or predictable outlooks is dependent on plans materialising as expected. If expectations are not met, this forms a disparity between one's present self and ideal self (Schwandt, 2016). The extent of any such disparity would then be dependent on an individual's sociodemographic context to control or maintain desired outcomes. Therefore, within the decline of happiness among young people, it is important for mitigation strategies to consider the role of time perspectives and temporal outlooks, but also the inherent disadvantages of many young people to attain their desired future self.

Our sample provided insight into how Australian young adults define happiness. However, a wider sample would have offered greater insight into the nuances between young people. Our abductive research strategy provided the opportunity to explore young people's thoughts on happiness as they understand it. The observations presented in this article prompt further research to quantify the impacts of temporal orientations, and their nuanced components, on young people's reported levels of happiness. This research has largely supported the continued relevance of previous typologies of happiness exploring how young Australians define happiness (Delle Fave et al., 2016). Notably, the emergence of temporal orientations within our sample's definitions of happiness confirms the importance of temporalities within key issues of youth research (Woodman \& Leccardi, 2015), such as their happiness and well-being more broadly. Within the context of this study, we believe that this perspective is key to understanding the decline of happiness from adolescence to adulthood.

\section{Appendix}

\begin{tabular}{|c|c|c|c|c|c|c|c|}
\hline Pseudonym & Sex & $\begin{array}{l}\text { Employ- } \\
\text { ment status }\end{array}$ & $\begin{array}{l}\text { Relation- } \\
\text { ship status }\end{array}$ & $\begin{array}{l}\text { Highest } \\
\text { level of edu- } \\
\text { cation }\end{array}$ & $\begin{array}{l}\text { Happiness } \\
\text { Label }\end{array}$ & $\begin{array}{l}\text { Time per- } \\
\text { spective }\end{array}$ & $\begin{array}{l}\text { Temporal } \\
\text { outlook }\end{array}$ \\
\hline Sarah & $\mathrm{F}$ & Employed & Partnered & $\begin{array}{c}\text { Bachelor's } \\
\text { degree }\end{array}$ & Purpose & Present & Predictable \\
\hline Olivia & $\mathrm{F}$ & Employed & Single & $\begin{array}{c}\text { Bachelor's } \\
\text { degree }\end{array}$ & Control & Past & Adaptable \\
\hline Emma & $\mathrm{F}$ & $\begin{array}{l}\text { Limited } \\
\text { employ- } \\
\text { ment \& } \\
\text { casual } \\
\text { work }\end{array}$ & Partnered & $\begin{array}{r}\text { Master's } \\
\text { degree }\end{array}$ & $\begin{array}{r}\text { External } \\
\text { events }\end{array}$ & Past & Uncertain \\
\hline Kelsey & $\mathrm{F}$ & $\begin{array}{l}\text { Employed } \\
\text { in two } \\
\text { jobs }\end{array}$ & Partnered & $\begin{array}{c}\text { Bachelor's } \\
\text { degree }\end{array}$ & Activity & Present & Adaptable \\
\hline Jack & M & Casual work & Single & $\begin{array}{r}\text { Master's } \\
\text { degree }\end{array}$ & Purpose & Future & Controllable \\
\hline
\end{tabular}




\begin{tabular}{|c|c|c|c|c|c|c|c|}
\hline Pseudonym & Sex & $\begin{array}{l}\text { Employ- } \\
\text { ment status }\end{array}$ & $\begin{array}{l}\text { Relation- } \\
\text { ship status }\end{array}$ & $\begin{array}{l}\text { Highest } \\
\text { level of edu- } \\
\text { cation }\end{array}$ & $\begin{array}{l}\text { Happiness } \\
\text { Label }\end{array}$ & $\begin{array}{l}\text { Time per- } \\
\text { spective }\end{array}$ & $\begin{array}{l}\text { Temporal } \\
\text { outlook }\end{array}$ \\
\hline Zoe & $\mathrm{F}$ & Employed & Single & $\begin{array}{c}\text { Bachelor's } \\
\text { degree }\end{array}$ & Purpose & Future & Controllable \\
\hline Liam & M & Employed & Partnered & $\begin{array}{l}\text { Bachelor's } \\
\text { degree }\end{array}$ & Content & Present & Adaptable \\
\hline Jacob & M & Employed & Partnered & $\begin{array}{c}\text { Bachelor's } \\
\text { degree }\end{array}$ & Control & Past & Controllable \\
\hline Dylan & M & $\begin{array}{l}\text { Employed } \\
\quad \text { in two } \\
\text { jobs }\end{array}$ & Partnered & $\begin{array}{c}\text { Bachelor's } \\
\text { degree }\end{array}$ & Content & Present & Predictable \\
\hline Jayden & M & Employed & Partnered & $\begin{array}{c}\text { Bachelor's } \\
\text { degree }\end{array}$ & Control & Present & Controllable \\
\hline Alex & M & Employed & Single & $\begin{array}{l}\text { Bachelor's } \\
\text { degree }\end{array}$ & Purpose & Present & Uncertain \\
\hline Jade & $\mathrm{F}$ & Casual work & Partnered & $\begin{array}{r}\text { Master's } \\
\text { degree }\end{array}$ & Content & Future & Adaptable \\
\hline Samantha & $\mathrm{F}$ & Employed & Single & $\begin{array}{c}\text { Bachelor's } \\
\text { degree }\end{array}$ & Content & Present & Uncertain \\
\hline Jake & M & Employed & Partnered & $\begin{array}{c}\text { High School } \\
\text { Certificate }\end{array}$ & Content & Present & Adaptable \\
\hline Ethan & M & $\begin{array}{l}\text { Unem- } \\
\text { ployed }\end{array}$ & Single & $\begin{array}{c}\text { High School } \\
\text { Certificate }\end{array}$ & Content & Present & Controllable \\
\hline $\mathrm{Bec}$ & $\mathrm{F}$ & Employed & Married & Diploma & Content & Present & Predictable \\
\hline Caitlin & $\mathrm{F}$ & Employed & Dating & $\begin{array}{l}\text { Doctor of } \\
\text { Philoso- } \\
\text { phy }\end{array}$ & Content & Present & Adaptable \\
\hline Luke & M & $\begin{array}{l}\text { Unem- } \\
\text { ployed }\end{array}$ & Single & $\begin{array}{r}\text { High School } \\
\text { Certificate }\end{array}$ & Fulfilment & Future & Uncertain \\
\hline Laura & $\mathrm{F}$ & Employed & Single & $\begin{array}{c}\text { Bachelor's } \\
\text { degree }\end{array}$ & Content & Present & Predictable \\
\hline Chris & M & Employed & Single & $\begin{array}{c}\text { High School } \\
\text { Certificate }\end{array}$ & Content & Present & Controllable \\
\hline Kyle & M & Employed & Partnered & $\begin{array}{r}\text { Master's } \\
\text { degree }\end{array}$ & Purpose & Future & Controllable \\
\hline Jane & $\mathrm{F}$ & Employed & Married & $\begin{array}{l}\text { Graduate } \\
\text { certificate }\end{array}$ & Belonging & Present & Predictable \\
\hline Isaac & M & Employed & Partnered & $\begin{array}{c}\text { Bachelor's } \\
\text { degree }\end{array}$ & Fulfilment & Present & Controllable \\
\hline Chloe & $\mathrm{F}$ & Employed & Dating & $\begin{array}{c}\text { High School } \\
\text { Certificate }\end{array}$ & Content & Present & Adaptable \\
\hline Brianna & $\mathrm{F}$ & Employed & Partnered & $\begin{array}{r}\text { Master's } \\
\text { degree }\end{array}$ & Content & Present & Predictable \\
\hline Joel & M & Employed & Single & $\begin{array}{c}\text { High School } \\
\text { Certificate }\end{array}$ & Content & Present & Adaptable \\
\hline Angus & M & Employed & Engaged & $\begin{array}{l}\text { Bachelor's } \\
\text { degree }\end{array}$ & Enjoyment & Present & Predictable \\
\hline Lily & $\mathrm{F}$ & $\begin{array}{l}\text { Unem- } \\
\text { ployed }\end{array}$ & Partnered & $\begin{array}{c}\text { High School } \\
\text { Certificate }\end{array}$ & Content & Present & Predictable \\
\hline
\end{tabular}




\begin{tabular}{llllllll}
\hline Pseudonym & Sex & $\begin{array}{l}\text { Employ- } \\
\text { ment status }\end{array}$ & $\begin{array}{l}\text { Relation- } \\
\text { ship status }\end{array}$ & $\begin{array}{l}\text { Highest } \\
\text { level of edu- } \\
\text { cation }\end{array}$ & $\begin{array}{l}\text { Happiness } \\
\text { Label }\end{array}$ & $\begin{array}{l}\text { Time per- } \\
\text { spective }\end{array}$ & $\begin{array}{l}\text { Temporal } \\
\text { outlook }\end{array}$ \\
\hline Brad & M & Employed & Dating & $\begin{array}{l}\text { Bachelor's } \\
\text { degree }\end{array}$ & Purpose & Present & Controllable \\
\hline
\end{tabular}

Funding This work was supported by the Australian Research Council (DP160100360).

Data availability Data is unavailable for public access.

\section{Declarations}

Ethics Approval All data collection and collection materials operationalised by the Our Lives Project were completed with full ethical approval from the Monash University Human Research Ethics Committee (MUHREC), with consent to participate received from each participant.

Conflict of Interest The authors declare no competing interests.

Open Access This article is licensed under a Creative Commons Attribution 4.0 International License, which permits use, sharing, adaptation, distribution and reproduction in any medium or format, as long as you give appropriate credit to the original author(s) and the source, provide a link to the Creative Commons licence, and indicate if changes were made. The images or other third party material in this article are included in the article's Creative Commons licence, unless indicated otherwise in a credit line to the material. If material is not included in the article's Creative Commons licence and your intended use is not permitted by statutory regulation or exceeds the permitted use, you will need to obtain permission directly from the copyright holder. To view a copy of this licence, visit http://creativecommons.org/licen ses/by/4.0/.

\section{References}

Agbo AA, Ome B (2017) Happiness: meaning and determinants among young adults of the Igbos of Eastern Nigeria. J Happiness Stud 18(1):151-175

Amit V (2011) 'Before I Settle Down': youth travel and enduring life course paradigms. Anthropologica 53(1):79-88

Archer, M. S. (1995). Realist social theory: the morphogenetic approach. Cambridge ; New York: Cambridge University Press.

Arnett JJ (2000) Emerging adulthood: a theory of development from the late teens through the twenties. Am Psychol 55(5):469-480

Barnett MD (2014) Future orientation and health among older adults: the importance of hope. Educ Gerontol 40(10):745-755

Bartram, D. (2020). Age and life satisfaction: getting control variables under control. Sociology, 003803852092687.

Bastian B, Kuppens P, De Roover K, Diener E (2014) Is valuing positive emotion associated with life satisfaction? Emotion 14(4):639-645

Blaikie NWH (2007) Approaches to social enquiry, 2nd edn. Polity, Cambridge

Blanchflower D, Oswald A (2008) Is well-being U-shaped over the life cycle? Soc Sci Med 66(8):1733-1749

Blanchflower D, Oswald A (2019) Do humans suffer a psychological low in midlife? Two approaches (with and without controls) in seven data sets. In: Rojas M (ed) The Economics of Happiness. Springer International Publishing, Cham, pp 439-453 
Boniwell I (2005) Beyond time management: how the latest research on time perspective and perceived time use can assist clients with time-related concerns. Int J Evid Based Coach Mentoring 3(2):61-74

Boniwell I, Osin E, Alex Linley P, Ivanchenko GV (2010) A question of balance: time perspective and well-being in British and Russian samples. J Posit Psychol 5(1):24-40

Brannen J, Nilsen A (2002) Young people's time perspectives: from youth to adulthood. Sociology 36(3):513-537

Carlquist E, Nafstad HE, Blakar RM (2018) Understanding satisfaction: an analysis of the meaning potential of the word "satisfaction" in everyday Norwegian language. J Happiness Stud 19(4):939-959

Caunt BS, Franklin J, Brodaty NE, Brodaty H (2013) Exploring the causes of subjective well-being: a content analysis of peoples' recipes for long-term happiness. J Happiness Stud 14(2):475-499

Chesters J, Smith J, Cuervo H, Laughland-Booÿ J, Wyn J, Skrbiš Z, Woodman D (2019) Young adulthood in uncertain times: the association between sense of personal control and employment, education, personal relationships and health. J Sociol 55(2):389-408

Chua LW, Milfont TL, Jose PE (2015) Coping skills help explain how future-oriented adolescents accrue greater well-being over time. J Youth Adolesc 44(11):2028-2041

Cook J (2016) Young adults' hopes for the long-term future: from re-enchantment with technology to faith in humanity. J Youth Stud 19(4):517-532

Côté J, Bynner JM (2008) Changes in the transition to adulthood in the UK and Canada: the role of structure and agency in emerging adulthood. J Youth Stud 11(3):251-268

Delle Fave A, Brdar I, Freire T, Vella-Brodrick D, Wissing MP (2011) The eudaimonic and hedonic components of happiness: qualitative and quantitative findings. Soc Indic Res 100(2):185-207

Delle Fave, A., Brdar, I., Wissing, M. P., Araujo, U., Castro Solano, A., Freire, T., ... Soosai-Nathan, L. (2016). Lay definitions of happiness across nations: the primacy of inner harmony and relational connectedness. Frontiers in Psychology, 7.

Drake L, Duncan E, Sutherland F, Abernethy C, Henry C (2008) Time perspective and correlates of wellbeing. Time \& Society 17(1):47-61

Felsman P, Verduyn P, Ayduk O, Kross E (2017) Being present: focusing on the present predicts improvements in life satisfaction but not happiness. Emotion 17(7):1047-1051

France, A. (2016). Understanding youth in the global economic crisis. Bristol; Chicago: Policy Press.

Glenn N (2009) Is the apparent U-shape of well-being over the life course a result of inappropriate use of control variables? A commentary on Blanchflower and Oswald (66: 8, 2008, 1733-1749). Soc Sci Med 69(4):481-485

Headey B (2008) Life goals matter to happiness: a revision of set-point theory. Soc Indic Res $86(2): 213-231$

Hoddy ET (2019) Critical realism in empirical research: employing techniques from grounded theory methodology. Int J Soc Res Methodol 22(1):111-124

Hussain D (2017) Conceptual referents, personality traits and income-happiness relationship: an empirical investigation. Europe's Journal of Psychology 13(4):733-748

Laaksonen S (2018) A research note: happiness by age is more complex than U-shaped. J Happiness Stud 19:471-482

Laughland-Booÿ J, Newcombe P, Skrbiš Z (2017) Looking forward: career identity formation and the temporal orientations of young Australians. J Vocat Behav 101:43-56

Leccardi, C. (2015). Young people and the new semantics of the future. SocietàMutamentoPolitica 5, 41-54 Paginazione.

Liao, T. F. (2021). Income inequality, social comparison, and happiness in the United States. Socius: Sociological Research for a Dynamic World, 7, 237802312098564.

McDonald P, Pini B, Bailey J, Price R (2011) Young people's aspirations for education, work, family and leisure. Work Employ Soc 25(1):68-84

Mogilner C, Kamvar SD, Aaker J (2011) The shifting meaning of happiness. Soc Psychol Pers Sci 2(4):395-402

Pflug J (2009) Folk theories of happiness: a cross-cultural comparison of conceptions of happiness in Germany and South Africa. Soc Indic Res 92(3):551-563

Piper AT (2015) Sliding down the U-shape? A dynamic panel investigation of the age-well-being relationship, focusing on young adults. Soc Sci Med 143:54-61

Roberts S, France A (2021) Problematizing a popular panacea: A critical examination of the (continued) use of 'social generations' in youth sociology. The Sociological Review 69(4):775-791. https://doi. org/10.1177/0038026120922467 
Rojas M (2005) A conceptual-referent theory of happiness: heterogeneity and its consequences. Soc Indic Res 74(2):261-294

Rojas M, Veenhoven R (2013) Contentment and affect in the estimation of happiness. Soc Indic Res 110(2):415-431

Rosa H (2013) Social acceleration: a new theory of modernity. Columbia University Press

Sayer, R. A. (2010). Method in social science a realist approach. London; New York: Routledge.

Schwandt H (2016) Unmet aspirations as an explanation for the age U-shape in wellbeing. J Econ Behav Organ 122:75-87

Skrbis, Z., Western, M., Tranter, B., Hogan, D., Coates, R., Smith, J., ... Mayall, M. (2012). Expecting the unexpected: young people's expectations about marriage and family. J Sociol, 48(1), 63-83

Skrbis Z, Tranter B, Western M, Smith J, Laughland-Booÿ J, Bean C, Parcell C, Hogan D (2020) Our Lives, Social Futures and Life Pathways of Young People in Queensland: A Longitudinal Project, 2006-2019 (Waves 1-7), ADA Dataverse. https://doi.org/10.26193/RAR7TH

Tomaszewski W, Smith J, Parsell C, Tranter B, Laughland-Booÿ J, Skrbiš Z (2016) Young, anchored and free? Examining the dynamics of early housing pathways in Australia. J Youth Stud 20(7):904-926

Torras M (2008) The subjectivity inherent in objective measures of well-being. J Happiness Stud 9(4):475-487

Veenhoven R (2010) How universal is happiness? In: Diener E, Helliwell JF, Kahneman D (eds) International differences in well-being. Oxford University Press, Oxford; New York, pp 328-350

Veenhoven R (2012) Does happiness differ across cultures? In: Selin H, Davey G (eds) Happiness Across Cultures, vol 6. Springer, Netherlands, Dordrecht, pp 451-472

Wood D, Crapnell T, Lau L, Bennett A, Lotstein D, Ferris M, Kuo A (2018) Emerging adulthood as a critical stage in the life course. In: Halfon N, Forrest CB, Lerner RM, Faustman EM (eds) Handbook of Life Course Health Development. Springer International Publishing, Cham, pp 123-143

Woodman D, Leccardi C (2015) Generations, transitions, and culture as practice: a temporal approach to youth studies. In: Woodman D, Bennett A (eds) Youth Cultures, Transitions, and Generations. Palgrave Macmillan UK, London, pp 56-68

Woodman, D., \& Wyn, J. (2015). Youth and generation: rethinking change and inequality in the lives of young people. Thousand Oaks, California : London: SAGE Publications Ltd. 